\title{
Interspecific Hybridization in Hazelnut (Corylus)
}

\author{
Veli Erdogan ${ }^{1}$ and Shawn A. Mehlenbacher ${ }^{2}$ \\ Department of Horticulture, Oregon State University, Corvallis, OR 97331
}

\begin{abstract}
AdDITIONAL INDEX wORDs. Corylus avellana, filbert, taxonomy, incompatibility, incongruity
Abstract. Eight Corylus L. (hazelnut) species were intercrossed in all possible combinations to reveal genetic relationships. Pollinations were made on either individually bagged branches or trees covered entirely with polyethylene using mixtures of pollen of five genotypes to minimize low cluster set due to single incompatible combinations. Percent cluster set, seed germination, and hybrid seedling survival were determined. Hybridity of seedlings was verified by inspection of morphological traits. Based on percent cluster set, seed germination, and hybrid seedling survival along with observed morphological similarities, Corylus species were placed in three groups: 1) the tree hazels C. colurna L. (turkish tree hazel) and $C$. chinensis Franchet (chinese tree hazel), 2) the bristle-husked shrub species $C$. cornuta Marshall (beaked hazel), C. californica (A.DC.) Rose (california hazel), and $C$. sieboldiana Blume (manchurian hazel), and 3) the leafy-husked shrub species C. avellana L. (european hazel), C. americana Marshall (american hazel), C. heterophylla Fischer (siberian hazel), and $C$. heterophylla Fischer var. sutchuensis Franchet (sichuan hazel). The two tree hazel species crossed with each other readily, as did the three bristle-husked shrub species. The frequency of blanks was low $(<20 \%)$ for crosses of the tree hazels, and $<\mathbf{5 0 \%}$ for interspecific crosses within the group of bristle-husked species. The leafy-husked shrub species could be crossed with each other in all directions, although cluster set on $C$. heterophylla was low. For crosses of species belonging to different groups, set was generally low and the frequency of blanks high. Nevertheless, a few hybrid seedlings were obtained from several combinations. When used as the female parent, $\boldsymbol{C}$. californica set nuts when crossed with all other species, indicating possible value as a bridge species. Crosses involving $C$. avellana were more successful when it was the pollen parent. In crosses with $C$. avellana pollen, cluster set on $C$. chinensis was better than on $C$. colurna and the frequency of blanks was much lower, indicating that it might be easier to transfer nonsuckering growth habit from $C$. chinensis than from $C$. colurna. Reciprocal differences in the success of crosses was observed. The following crosses were successful $C$. californica $\times C$. avellana, $C$. chinensis $\times C$. avellana, $C$ americana $\times C$. heterophylla, $C$. cornuta $\times$ C heterophylla, $C$. californica $\times$ C. colurna, and $C$. americana $\times$ C. sieboldiana, but the reciprocals were not.
\end{abstract}

Hazelnut is the common name for species of the genus Corylus, which are members of the birch family, Betulaceae, of the order Fagales. Taxonomists have described as many as 25 Corylus species (Bailey, 1914; Everett, 1981; Huxley et al., 1992; Kasapligil, 1972; Krussman, 1976; Rehder, 1940). Of these, five shrub and four tree species are most commonly recognized (Thompson et al., 1996). The shrub species are C. avellana (european hazel), C. americana (american hazel), C. cornuta (beaked hazel), C. heterophylla (siberian hazel), and C. sieboldiana (manchurian hazel); the tree species are $C$. colurna (turkish tree hazel), C. jacquemontii Decne. (indian tree hazel), C. chinensis (chinese tree hazel), and C. ferox Wallich. (tibetan tree hazel).

Corylus species are widely distributed throughout temperate regions of the Northern Hemisphere from Japan, China, from Manchuria through Tibet, the Caucasus mountains, Turkey, Europe, and North America (Ayfer et al., 1986; Kasapligil, 1972). They are deciduous trees and shrubs. All species are monoecious and wind-pollinated (Lagerstedt, 1975). The chromosome number of the genus is $2 n=2 x=22$ (Thompson et al., 1996). Hazelnuts are not native to the Southern Hemisphere and native fossil forms have not yet been discovered in this area of the world (Kasapligil, 1972).

The European hazelnut, C. avellana, is the species of commerce and is genetically diverse (Mehlenbacher, 1991; Rovira,

\footnotetext{
Received for publication 5 Oct. 1999. Accepted for publication 31 Jan. 2000 Oregon Agricultural Experiment Station technical paper 11579. We thank Curator Kim Hummer for allowing use of trees at the USDA National Clonal Germplasm Repository, Corvallis, Ore. The cost of publishing this paper was defrayed in part by the payment of page charges. Under postal regulations, this paper therefore must be hereby marked advertisement solely to indicate this fact. ${ }^{1}$ Current address: Dept. of Horticulture, Faculty of Agriculture, Ankara University, 06110 Diskapi, Ankara, Turkey.

2Professor; to whom reprint requests should be sent; e-mail mehlenbs@bcc.orst.edu.
}

1997). The important commercial cultivars in Europe and Turkey were selected over many centuries from local wild populations of this species. Nuts of $C$. avellana have larger size, thinner shells, and superior quality kernels, and thus this species has been used extensively in breeding programs. However, some highly desirable and economically important traits such as nonsuckering growth habit, tolerance to alkaline soil, extreme precocity, exceptionally early maturity, cold hardiness, and alternate sources of resistance to eastern filbert blight caused by Anisogramma anomala (Peck) E. Müller do not exist within C. avellana but do exist in wild species (Thompson et al., 1996). Interspecific hybridization then becomes necessary to transfer those characters from wild species. Interspecific hybridization has been reported by Farris (1989), Gellatly (1950, 1956, 1964, 1966), Liang et al. (1994), Reed (1936), Slate (1961), and Weschcke (1970). Most studies have concentrated on crosses of wild species with the economically important $C$. avellana. The crossability of many Asian species with the cultivated hazelnut has not yet been documented. In other cases, reports are conflicting and clarification is needed. Previous attempts indicate that some Corylus species intercross freely, some cross with difficulty, some cross in one direction, and some do not cross in either direction (Erdogan and Mehlenbacher, 1997; Mehlenbacher, 1991; Thompson et al., 1996).

An effort to collect representatives of all hazelnut species from natural, wild populations is in progress at Oregon State University and at the U.S. Department of Agriculture, National Clonal Germplasm Repository, Corvallis, Ore. Many representatives of these species had reached maturity and were available for this study.

The objective of this study was to obtain information about the crossability of Corylus species using taxonomically verified genotypes. This information will provide insight into phylogenetic relationships and facilitate their use in hazelnut breeding. 


\section{Materials and Methods}

Genetic Material. Controlled pollinations were performed in 1995, 1996, and 1997 at the Smith Horticulture Research Farm of Oregon State University, and the U.S. Department of Agriculture, National Clonal Germplasm Repository. Several female and male parents were used for each species (Tables 1 and 2). Wild species were represented by seedlings grown from seeds collected in wild stands as well as grafted trees propagated from imported scions. When seedlings were used as female parents, two seedlings from the same seed lot were generally used to provide a sufficient number of female inflorescences. Cultivars and advanced selections from the Oregon State University breeding program with known S-alleles were used for $C$. avellana. Female parents (Table 1) were selected based on their performance in previous years, plant size, time of flowering, and male flower (catkin) number which is an indication of the abundance of female flowers. We planned to use at least two different female genotypes for each species every year. However, it was not possible in some cases. For $C$. colurna, only two genotypes were available and alternate bearing was pronounced. Many juvenile seedlings of $C$. chinensis were in the collection, but only one was in the adult growth phase as this species has a long juvenile phase. In C. heterophylla, female flowers were rare on most seedlings as well as selections. Also, during the course of this investigation, wind and heavy rain storms damaged a few pollination cages, and floods lifted a few cages and allowed unwanted open pollination (C. americana). This reduced the amount of data collected.

Newly elongated catkins were collected from many genotypes in each wild species because no information was available about their pollen quality or quantity. Some species, particularly $C$. cornuta and $C$. heterophylla, produced only a few very small catkins that yielded small amounts of pollen. Collected catkins were brought to the lab in the afternoon, laid on paper, and allowed to dry overnight at $20^{\circ} \mathrm{C}$. As they dried, the anthers dehisced and shed pollen on the paper. Pollen was collected and

Table 1. Female parents of Corylus species and genotypes used in crosses (1995-97).

\begin{tabular}{|c|c|c|c|}
\hline Species & Year & Genotype & Origin \\
\hline \multirow[t]{5}{*}{ C. avellana } & 1995 & Ennis $\left(\mathrm{S}_{1} \mathrm{~S}_{11}\right)^{\mathrm{z}}$ & Washington \\
\hline & 1995 & Casina $\left(\bar{S}_{10} \mathrm{~S}_{21}\right)$ & Asturias, Spain \\
\hline & 1996 & $276.076\left(\mathrm{~S}_{1} \mathrm{~S}_{8}\right)$ & Tombul Ghiaghli, Greece x Willamette, Ore. \\
\hline & 1997 & Butler $\left(\mathrm{S}_{2} \mathrm{~S}_{3}\right)^{\underline{q}}$ & Oregon \\
\hline & 1997 & $245.098\left(\mathrm{~S}_{3} \mathrm{~S}_{8}\right)$ & (Barcelona, Spain x Tombul Ghiaghli, Greece) x Willamette, Ore. \\
\hline \multirow[t]{5}{*}{ C. americana } & 1995 & COR 059 (2 seedlings) & Mississippi \\
\hline & 1996 & 88301 (2 seedlings) & Pennsylvania \\
\hline & 1996 & 88309 (2 seedlings) & Kentucky \\
\hline & 1997 & 88312 (2 seedlings) & New Jersey \\
\hline & 1997 & 88317 ( 2 seedlings) & Iowa \\
\hline \multirow[t]{6}{*}{ C. heterophylla } & 1995 & Het 001 & Korea \\
\hline & 1995 & Het 013 & Korea \\
\hline & 1996 & 86025 (1 seedling) & Korea \\
\hline & 1996 & Het 013 & Korea \\
\hline & 1997 & 88452 (2 seedlings) & China \\
\hline & 1997 & COR 067 (1 seedling) & China \\
\hline \multirow[t]{6}{*}{ C. cornuta } & 1995 & 88403 (3 seedlings) & New York \\
\hline & 1995 & 84016 (2 seedlings) & British Columbia, Canada \\
\hline & 1996 & 88401 ( 2 seedlings) & Quebec, Canada \\
\hline & 1996 & 89413 (2 seedlings) & Manitoba, Canada \\
\hline & 1997 & 89404 ( 2 seedlings) & New York \\
\hline & 1997 & 89401 ( 2 seedlings) & Wisconsin \\
\hline \multirow[t]{5}{*}{ C. californica } & 1995 & B0509 & Oregon \\
\hline & 1995 & B0849 & Oregon \\
\hline & 1996 & SCS 21-5 & Oregon \\
\hline & 1997 & SCS 58-5 & Oregon \\
\hline & 1997 & SCS 59-1 & Oregon \\
\hline \multirow[t]{6}{*}{ C. sieboldiana } & 1995 & 87801 (2 seedlings) & Korea \\
\hline & 1995 & COR 350 & Korea \\
\hline & 1996 & 86030 ( 2 seedlings $)$ & Korea \\
\hline & 1996 & 86031 (1 seedling) & Korea \\
\hline & 1997 & 86028 ( 2 seedlings) & Korea \\
\hline & 1997 & 86029 ( 2 seedlings $)$ & Korea \\
\hline \multirow[t]{4}{*}{ C. colurna } & 1995 & $\mathrm{X} 11$ & Europe \\
\hline & 1995 & $\mathrm{X} 13$ & Europe \\
\hline & 1996 & $\mathrm{X} 11$ & Europe \\
\hline & 1997 & $\mathrm{X} 13$ & Europe \\
\hline \multirow[t]{2}{*}{ C. chinensis } & 1996 & W5 & China \\
\hline & 1997 & W5 & China \\
\hline
\end{tabular}

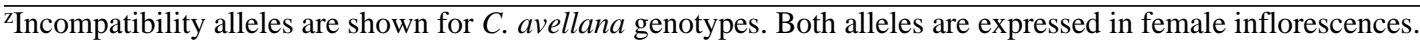


stored in cotton-stoppered glass vials at $-18{ }^{\circ} \mathrm{C}$ until used. Genotypes with good pollen quantity and quality (fine powder rather than coarse granules) were selected as male parents (Table 2 ). For $C$. avellana, the S-alleles of the genotypes were known. Sporophytic pollen-stigma incompatibility in C. avellana has been well-studied (Mehlenbacher, 1997; Thompson, 1979a, $1979 b$ ) but this information is not available for the wild Corylus species. Thus, mixtures of pollen of five genotypes for each species were used to minimize the potential for low cluster set due to pollen-stigma incompatibility.

Crosses. Controlled crosses were made on individual branches or entire trees depending on plant size. Female parents were emasculated before the start of pollen shed and emergence of female flowers. Individual branches were bagged in Tyvek (Dupont) housewrap (Smith and Mehlenbacher, 1994). The Tyvek bag was enclosed in a cotton-polyester bag for protection from punctures and abrasion. Entire trees were enclosed in wooden framed structures covered with white polyethylene. Female flow- ers were pollinated by hand when styles were visible outside the bud or were exserted beyond the red dot stage $(>2 \mathrm{~mm})$. Female flowers of some species emerge in January yet pollen of other species is not available until April, and set declines as flowers age. In 1996 and 1997, stored pollen from the previous year was used in crosses for late-shedding species $C$. cornuta, $C$. californica, and $C$. sieboldiana to minimize the effect of flower age, but fresh pollen was used in 1995 crosses. Several of the wild species genotypes had not been used previously as female parents, and their ability to set nut clusters was unknown. Hybrid seeds were harvested when the nuts could be easily turned in the husk in August, September or October depending on the year and species. The numbers of pollinated flowers and harvested nut clusters were counted and percent cluster set was calculated as the ratio of nut clusters to flowers pollinated. Crosses with percent cluster set $>10 \%$ were considered compatible, crosses with $<5 \%$ cluster set were considered incompatible and cluster set between $5 \%$ and $10 \%$ was considered intermediate. Data from trees in pollination

Table 2. Male genotypes used in pollen mixtures for Corylus crosses.

\begin{tabular}{|c|c|c|c|}
\hline \multirow[b]{2}{*}{ Species } & \multicolumn{3}{|c|}{ Genotype } \\
\hline & 1995 & 1996 & 1997 \\
\hline \multirow[t]{5}{*}{ C. avellana } & $243.002\left(\mathrm{~S}_{3} \mathrm{~S}_{8}\right)^{\mathrm{Z}}$ & Mortarella $\left(\mathrm{S}_{2} \mathrm{~S}_{17}\right)$ & Casina $\left(\mathrm{S}_{10} \mathrm{~S}_{21}\right)$ \\
\hline & $256.005\left(\mathrm{~S}_{2}^{\underline{\underline{2}}} \mathrm{~S}_{4}^{\underline{\underline{-}}}\right)$ & $264.148\left(\mathrm{~S}_{2} \mathrm{~S}_{12}\right)^{\frac{11}{1}}$ & $228.084\left(\mathrm{~S}_{1} \frac{21}{\mathrm{~S}_{2}}\right)$ \\
\hline & $278.113\left(\mathrm{~S}_{7} \mathrm{~S}_{8}\right)$ & $452.014\left(\mathrm{~S}_{4} \mathrm{~S}_{19}\right)$ & $313.078\left(\mathrm{~S}_{2} \mathrm{~S}_{12}\right)$ \\
\hline & $381.053\left(\mathrm{~S}_{2} \mathrm{~S}_{12}^{\underline{\underline{0}}}\right)$ & $464.029\left(\mathrm{~S}_{2} \mathrm{~S}_{5}\right)$ & $455.087\left(\mathrm{~S}_{9} \mathrm{~S}_{20}\right)$ \\
\hline & $443.107\left(\mathrm{~S}_{1} \mathrm{~S}_{2}\right)$ & $513.007\left(\mathrm{~S}_{\underline{5}} \mathrm{~S}_{9}\right)$ & $513.007\left(\mathrm{~S}_{\underline{5}} \mathrm{~S}_{9}\right)$ \\
\hline \multirow[t]{5}{*}{ C. americana } & 403.040 & 356.063 & 400.008 \\
\hline & 530.081 & 366.069 & 401.023 \\
\hline & 531.034 & 401.028 & 530.039 \\
\hline & 532.014 & 405.070 & 532.014 \\
\hline & 532.069 & 530.063 & 532.061 \\
\hline \multirow[t]{5}{*}{ C. heterophylla } & 402.009 & $\mathrm{~T} 26$ & 404.045 \\
\hline & 402.050 & 402.009 & 404.061 \\
\hline & 404.010 & 404.023 & 530.015 \\
\hline & 404.054 & 530.025 & 530.021 \\
\hline & 406.007 & 559.062 & 559.059 \\
\hline C. heterophylla var.sutchuensis & --- & --- & $566.044^{y}$ \\
\hline \multirow[t]{5}{*}{ C. cornuta } & $\mathrm{CC} 3.002$ & CC3.006 & CC $3.038^{\mathrm{y}}$ \\
\hline & $\mathrm{CC} 3.024$ & CC3.054 & CC3.059 \\
\hline & CC4.002 & CC4.007 & $\mathrm{CC} 4.007$ \\
\hline & CC4.039 & $\mathrm{CC} 4.025$ & $\mathrm{CC} 4.024$ \\
\hline & $\mathrm{CC} 4.052$ & $\mathrm{CC} 4.053$ & $\mathrm{CC} 4.034$ \\
\hline \multirow[t]{5}{*}{ C. californica } & X37 & $X 37^{x}$ & $\mathrm{Y} 30^{\mathrm{y}}$ \\
\hline & X39 & X39 & Y31 \\
\hline & $\mathrm{Y} 20$ & Y20 & CC2.088 \\
\hline & Y34 & Y34 & $\mathrm{CC} 1.100$ \\
\hline & CC2.040 & CC2.040 & CC1.103 \\
\hline \multirow[t]{5}{*}{ C. sieboldiana } & $\mathrm{CC} 1.021$ & $\mathrm{CC} 1.021^{\mathrm{x}}$ & $\mathrm{CC} 1.043^{\mathrm{y}}$ \\
\hline & CC1.043 & $\mathrm{CC} 1.043$ & $\mathrm{CC} 1.057$ \\
\hline & $\mathrm{CC} 1.061$ & $\mathrm{CC} 1.061$ & $\mathrm{CC} 2.070$ \\
\hline & CC4.103 & CC4.103 & $\mathrm{CC} 2.073$ \\
\hline & CC4.104 & CC4.104 & CC4.104 \\
\hline \multirow[t]{3}{*}{ C. colurna } & $\mathrm{X} 11$ & $\mathrm{X} 11$ & $\mathrm{X} 11$ \\
\hline & $\mathrm{X} 13$ & $\mathrm{X} 13$ & $\mathrm{X} 13$ \\
\hline & --- & Peavy & Peavy \\
\hline C. chinensis & --- & W5 & W5 \\
\hline
\end{tabular}

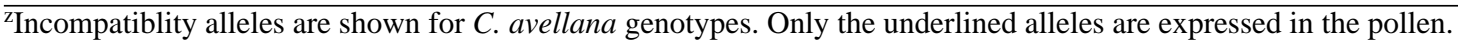

y Pollen of C. heterophylla var. sutchuensis, C. cornuta, C. californica, and C. sieboldiana used for 1997 pollinations was collected in 1996 and stored at $-18{ }^{\circ} \mathrm{C}$.

${ }^{x}$ Pollen of $C$. californica and C. sieboldiana used for 1996 pollinations was collected in 1995 and stored at $-18^{\circ} \mathrm{C}$. 
Table 3. Percent cluster set of intra- and interspecific hazelnut crosses (1995-97) ${ }^{\mathrm{z}}$. Bulked pollen was use for the male parents (Table 2). The female parents are listed in Table 1. Results are presented for each year, and the average of the 3 years.

\begin{tabular}{|c|c|c|c|c|c|c|c|c|c|c|c|c|c|}
\hline \multirow[b]{3}{*}{ Female parent } & \multicolumn{13}{|c|}{ Male parent } \\
\hline & \multicolumn{4}{|c|}{ AVE } & \multicolumn{4}{|c|}{ AME } & \multicolumn{4}{|c|}{ HET } & \multirow{2}{*}{$\frac{\text { HET SUT }^{2}}{97}$} \\
\hline & 95 & 96 & 97 & Avg & 95 & 96 & 97 & Avg & 95 & 96 & 97 & Avg & \\
\hline C. avellana (AVE) & 38.1 & 73.9 & 64.7 & 58.9 & 11.7 & 46.3 & 48.1 & 35.4 & 0.1 & 47.1 & 35.0 & 27.4 & 43.4 \\
\hline C. americana (AME) & 40.5 & 20.2 & 60.3 & 40.3 & 45.8 & 44.1 & 43.8 & 44.6 & 29.2 & 28.5 & 63.3 & 40.3 & 65.0 \\
\hline C. heterophylla (HET) & 1.8 & 0.0 & 6.0 & 2.6 & 0.2 & 0.0 & 1.7 & 0.6 & 9.4 & 35.0 & 13.5 & 19.5 & 15.7 \\
\hline C. cornuta (COR) & 0.0 & 7.2 & 5.5 & 4.2 & 4.2 & 0.7 & 4.6 & 3.2 & 19.0 & 17.4 & 59.2 & 31.9 & 1.9 \\
\hline C. californica (CAL) & 9.1 & 48.3 & 51.5 & 36.3 & 10.6 & 13.3 & 40.9 & 21.6 & 5.0 & 56.0 & 48.5 & 36.5 & 28.7 \\
\hline C. sieboldiana (SIE) & 0.0 & 0.1 & 0.0 & 0.0 & 0.0 & 0.6 & 2.7 & 1.1 & 0.0 & 8.6 & 2.2 & 3.6 & 1.6 \\
\hline C. colurna (COL) & 6.5 & 30.4 & 24.0 & 20.3 & 3.2 & 11.1 & 2.0 & 4.8 & 2.1 & 14.3 & 0.0 & 5.5 & 0.0 \\
\hline C. chinensis $(\mathrm{CHI})$ & --- & 35.7 & 47.6 & 41.7 & --- & 0.0 & 28.6 & 14.3 & --- & 0.0 & 0.0 & 0.0 & 0.0 \\
\hline
\end{tabular}

${ }^{\mathrm{z}}$ Corylus heterophylla var. sutchensis. Abbreviations for other species are listed in the first column of this table.

yThe one available tree of $C$. chinensis set no nuts when self-pollinated.

cages damaged by storms or floods were regarded as unreliable and were deleted.

SEED GERMinATION AND SEEDLING GROWTH. In 1995, all available hybrid seeds of most crosses were used. For crosses that had high cluster set, a random sample of 200 seeds was used. A total of 3012 kernels were extracted from nuts by hand-cracking the shells. Numbers of empty nuts and abnormal embryos were recorded. To break dormancy, seeds were treated with gibberellic acid $\left(\mathrm{GA}_{3}\right)$ at $50 \mathrm{mg} \cdot \mathrm{L}^{-1}$ for $48 \mathrm{~h}$ in November (Mehlenbacher, 1994). After treatment, seeds were placed between two layers of moist filter paper in plastic boxes, and planted in flats as radicles emerged. Plantings were repeated at intervals of 7 to $20 \mathrm{~d}$. About 50 seedlings per cross were transplanted into $4-\mathrm{L}$ plastic pots when radicles were 15 to $25 \mathrm{~cm}$ long. A mix of 4 peatmoss : 3 volcanic pumice : 3 douglas fir [Pseudotsuga menziesii (Mirb.) Franco] bark (by volume) was used as the growing medium. Seedlings were grown in the greenhouse at $24{ }^{\circ} \mathrm{C}$ days $/ 18{ }^{\circ} \mathrm{C}$ nights and natural day length. At the time of transplanting, $9 \mathrm{~g}$ of Sierra 3- to 4-month release fertilizer $(17 \mathrm{~N}-2.6 \mathrm{P}-10 \mathrm{~K}$ with micronutrients) was added to each pot. Supplemental fertilizer (Peters' 20N-8.7P-16.6K) was applied as needed during the growing season. The seedlings were moved outdoors for chilling in December 1996 and planted in a nursery row in July 1997.

Similar procedures were followed for hybrid seeds from 1996 crosses. All hybrid seeds for most crosses and 100 random seeds for the few crosses that had high cluster set were used. The seeds were stratified in moist vermiculite at $5{ }^{\circ} \mathrm{C}$ from $11 \mathrm{Dec} .1996$ to 27 Mar. 1997. Before stratification, nuts were surface sterilized with $2.6 \%$ sodium hypochlorite for $1 \mathrm{~min}$. At the end of stratification, 204 germinated nuts were planted. Nongerminated nuts were cracked by hand and kernels were extracted and treated with $\mathrm{GA}_{3}$ at $50 \mathrm{mg} \cdot \mathrm{L}^{-1}$ for $24 \mathrm{~h}$. Over the following $42 \mathrm{~d}, 1242$ embryos germinated. The remaining 74 seeds were retreated with $\mathrm{GA}_{3}$, then planted. A total of 935 seedlings were transplanted. Greenhouse-grown seedlings were moved outdoors in December 1997 and planted in a nursery row in June 1998.

The frequency of blanks (empty nuts) was determined by visual inspection. Many blanks could be identified by external characteristics such as shell color, presence of large black spots on the shell, adherence to the husk, and light weight. Otherwise, the nuts were cracked and the absence of an embryo, very small embryo size, or abnormal embryo development were recorded.

Hybridity of seedlings was verified as they grew outdoors under natural conditions by observing species-specific morpho- logical characters such as leaf shape and size, lesions or spots on leaves, trunk color, and bark appearance. Seedling survival was noted from just after emergence to the day of field planting. Stem diameter of seedlings was measured at the soil line in the dormant season with a digital caliper (Mitutoyo Mfg. Co. Ltd., Tokyo, Japan) when 1995 and 1996 seedlings were 14 and 9 months old, respectively. Seedling stem diameter in centimeters indicated vigor as follows: weak $(<0.5 \mathrm{~cm})$, moderate $(0.5$ to $0.8 \mathrm{~cm})$, vigorous $(0.8$ to $1.0 \mathrm{~cm})$, and very vigorous $(>1.0 \mathrm{~cm})$.

\section{Results}

Interspecific crosses resulted in a wide range of cluster set from $0 \%$ to $78 \%$ (Table 3 ), and allowed assignment of the species to three groups: the tree hazels $C$. colurna and $C$. chinensis, the bristle-husked shrub species $C$. cornuta, $C$. californica, and $C$. sieboldiana, and the leafy-husked shrub species $C$. avellana, $C$. americana, and $C$. heterophylla. The frequency of blank nuts in these crosses ranged from $4 \%$ to $100 \%$.

Percent Cluster set and frequency of blank nuts in INTRASPECIFIC AND INTRAGROUP CROSSES. Percent cluster set of intraspecific crosses ranged from $20 \%$ in C. heterophylla to $59 \%$ in $C$. avellana (Table 3 ). The tree hazels $C$. colurna and $C$. chinensis set well and produced few blank nuts when crossed in either direction. The one bearing tree of $C$. chinensis was selfincompatible. Intraspecific crosses of the bristle-husked shrub species averaged $43 \%$ cluster set and $23 \%$ blanks. Set of interspecific crosses within this group was slightly lower, and the frequency of blanks slightly higher. Set of intraspecific crosses was high for C. avellana and C. americana, but low for C. heterophylla. Similarly, interspecific crosses among these three leafy-husked shrub species set well when $C$. avellana and $C$. americana were the female parents, but set was low on all crosses in which $C$. heterophylla was the female. Blank nuts were present, but the frequency was sufficiently low and interspecific hybrid seedlings were obtained readily. In 1997, a single tree of C. heterophylla var. sutchuensis as a pollen parent yielded good set on all three leafy-husked species. The frequency of blanks was quite high, however (74\% on C. avellana and $89 \%$ on C. heterophylla). Corylus avellana exhibited good cross compatibility with $C$. americana in both directions. Corylus avellana yielded good $(27 \%)$ cluster set when pollinated with $C$. heterophylla but set was very low (3\%) for the reciprocal crosses.

Percent Cluster Set and Frequency of Blank NUTS IN 


\begin{tabular}{|c|c|c|c|c|c|c|c|c|c|c|c|c|c|c|c|c|}
\hline \multicolumn{17}{|c|}{ Male parent } \\
\hline \multicolumn{4}{|c|}{$\mathrm{COR}$} & \multicolumn{4}{|c|}{ CAL } & \multicolumn{4}{|c|}{ SIE } & \multicolumn{4}{|c|}{$\mathrm{COL}$} & \multirow{2}{*}{$\frac{\text { CHI }}{97}$} \\
\hline 95 & 96 & 97 & Avg & 95 & 96 & 97 & Avg & 95 & 96 & 97 & Avg & 95 & 96 & 97 & Avg & \\
\hline 0.1 & 0.0 & 0.0 & 0.0 & 0.0 & 0.0 & 0.0 & 0.0 & 0.3 & 0.0 & 0.0 & 0.1 & 0.0 & 21.3 & 0.0 & 7.1 & 0.0 \\
\hline 0.0 & 0.0 & 8.1 & 2.7 & 2.4 & 12.8 & 0.0 & 5.1 & 22.4 & 43.8 & 43.3 & 36.5 & 0.7 & 9.0 & 0.0 & 3.2 & 3.4 \\
\hline 0.0 & 0.0 & 0.0 & 0.0 & 0.0 & --- & 0.0 & 0.0 & 0.0 & --- & 0.4 & 0.2 & 0.0 & --- & 1.1 & 0.5 & 3.3 \\
\hline 32.7 & 28.5 & 46.2 & 35.8 & 32.2 & 61.1 & 29.3 & 40.9 & 44.5 & 40.0 & 63.8 & 49.4 & 0.0 & 0.0 & 11.9 & 4.0 & 0.0 \\
\hline 40.7 & 51.4 & 45.0 & 45.7 & 45.2 & 35.4 & 53.3 & 44.6 & 44.4 & 15.4 & 55.4 & 38.4 & 15.6 & 20.0 & 45.7 & 27.1 & 10.0 \\
\hline 18.6 & 35.7 & 21.1 & 25.1 & 32.9 & 14.1 & 38.3 & 28.4 & 32.6 & 52.4 & 58.6 & 47.9 & 0.0 & 0.0 & 1.8 & 0.6 & 0.0 \\
\hline 0.0 & 0.0 & 0.0 & 0.0 & 0.0 & 2.2 & 0.0 & 0.7 & 0.0 & 3.0 & 0.0 & 1.0 & 22.1 & 20.0 & 47.6 & 29.9 & 40.0 \\
\hline --- & 0.0 & 0.0 & 0.0 & --- & 0.0 & 23.1 & 11.6 & --- & 0.0 & 0.0 & 0.0 & --- & 42.9 & 77.8 & 60.4 & $0.0^{\mathrm{y}}$ \\
\hline
\end{tabular}

INTERGROUP CROSSES. Very low set was observed in many crosses of species in different groups (Table 3, Fig. 1). Reciprocal differences in the success of crosses were common, and the frequency of blank nuts was often high (Table 4). The European species, C. avellana, was not cross-compatible with $C$. cornuta or C. sieboldiana in either direction. Crosses of $C$. avellana with $C$. californica and C. chinensis set clusters (36\% and $42 \%$, respectively) only when $C$. avellana was the pollen parent. Corylus colurna $\times$ C. avellana set clusters $(20 \%)$ when C. avellana was the pollen parent, but nearly all $(92 \%)$ of the nuts were blanks. The reciprocal cross, $C$. avellana $\times C$. colurna, set nuts in only one of the three years. Corylus americana was not cross-compatible with $C$. colurna or $C$. cornuta in either direction as indicated by the low cluster set. Corylus americana set nuts with $C$. chinensis and C. californica ( $14 \%$ and $22 \%$, respectively) when C. americana was the pollen parent. In contrast, $C$. americana crosses were only successful with $C$. sieboldiana (37\%) when C. americana was the maternal parent. Corylus heterophylla yielded low cluster set as a female parent in inter- as well as intraspecific crosses. Corylus heterophylla showed good cross-compatibility with $C$. cornuta $(32 \%)$ and $C$. californica $(37 \%)$ only as the pollen parent, and was not cross-compatible with $C$. colurna, $C$. chinensis or $C$. sieboldiana in either direction. Corylus cornuta and $C$. sieboldiana were not compatible with $C$. colurna or $C$. chinensis in either direction. Corylus californica was only cross-compatible with $C$. colurna when the latter was the pollen parent (27\%). Corylus californica was unusual in that, particularly as a female parent, it could be crossed with all other species.

All crosses resulted in some empty nut (blank) formation (Table 4). The frequency of blanks ranged from $4 \%$ to $100 \%$. Empty or blank nuts were mostly small in size and tightly adhered to the husk. The color of the shell was usually lighter. Some shells had large black spots on them, and in some nuts, part of the shell had collapsed. Most blank nuts had very small ( $\approx 1$ to $2 \mathrm{~mm}$ in size) dark brown ovule(s) at the end of the funiculus and some fiber in the shell. In other blanks, the embryo was $<1 / 3$ of full size and shriveled. In many of the incompatible combinations (low cluster set), most of the nuts were blank. For example, $C$. avellana $\times C$. cornuta produced few nuts, and $67 \%$ of those were blanks, while all of the nuts $(100 \%)$ of the reciprocal were empty. However, combinations with higher percent cluster set produced fewer blanks. For example, C. avellana $\times$ C. americana and its reciprocal resulted in $16 \%$ and $27 \%$ blanks, respectively.

All species produced some abnormal embryos, which were usually about half the size of normal embryos. Split cotyledons and shrunken cotyledons were common. Unequally developed cotyledons, seedcoats failing to completely cover the cotyledons and reversely oriented root and shoot axes were also observed during germination. Corylus californica, C. cornuta, and $C$. americana had an especially high number of abnormal embryos. Interestingly, most of those abnormal embryos resulted from intraspecific crosses. The lowest frequency of abnormal embryos was in crosses in which $C$. avellana was a parent, either as a female or male.

SEED GERMINATION AND SEEDLING GROWTH. Germination of the hybrid seeds from 1995 crosses continued for $100 \mathrm{~d}$. GA 3 treatment to break seed dormancy caused some seedlings to grow taller but weaker due to elongated stems. Some seed decay occurred in almost all hybrid seed lots and was most serious on $C$. avellana seeds. Germination for C. avellana was 35\% in 1995 due to decay compared to $68 \%$ in 1996 (Table 5). Fungicide treatments did not prevent decay but slowed the spread to some extent.

Most (87\%) of the 1996 hybrid seeds failed to germinate after 3.5 months of stratification. $\mathrm{GA}_{3}$ treatment was necessary, and

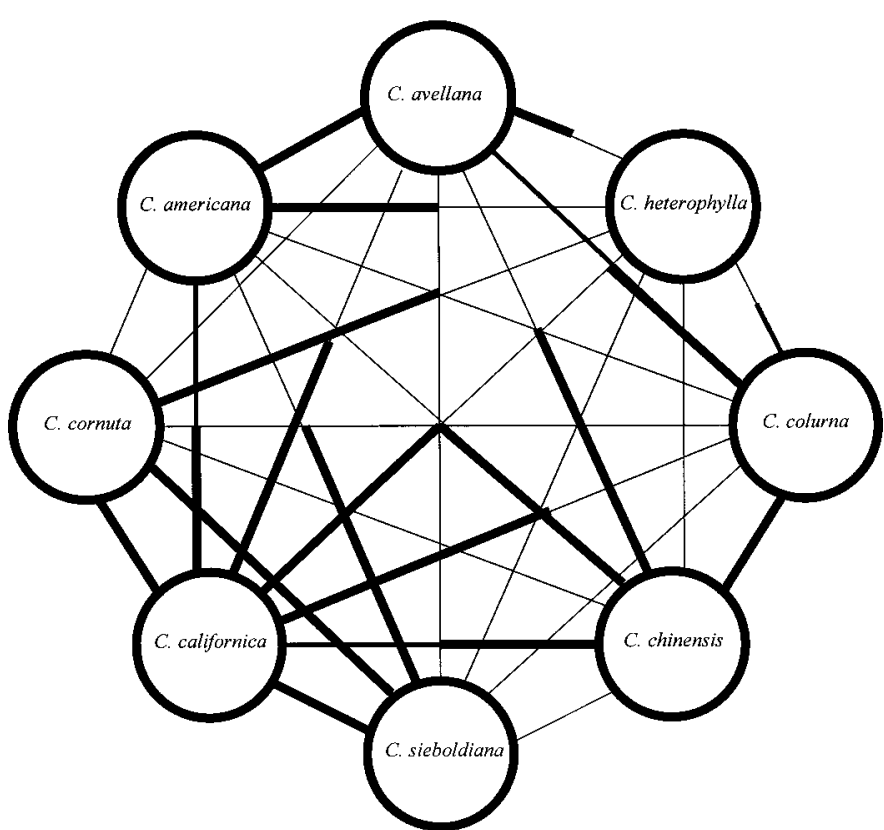

Fig. 1. Compatibility of interspecific crosses in Corylus based on percent cluster set. The width of the lines indicates the amount of set: thin $0 \%$ to $5 \%$, medium $5.1 \%$ to $10 \%$, and thick $10.1 \%$ to $25 \%$. Single lines with two widsths indicate reciprocal differences in the set of crosses. For $C$. chinensis $\times$ C. avellana, for example, the wide line touches the circle for $C$. chinensis, indicating that success is higher when it is the female parent but the reciprocal cross gives poor or no set. 
Table 4. Frequency (\%) of blank nuts in intra- and interspecific hazelnut crosses. Values are based on the total number of nuts obtained from each combination (1995-97).

\begin{tabular}{|c|c|c|c|c|c|c|c|c|c|}
\hline \multirow[b]{2}{*}{ Female parent } & \multicolumn{9}{|c|}{ Male parent } \\
\hline & AVE & AME & HET & HET SUT $^{z}$ & COR & CAL & SIE & $\mathrm{COL}$ & $\mathrm{CHI}$ \\
\hline C. avellana (AVE) & 18.3 & 16.3 & 39.4 & 73.8 & 66.7 & 0.0 & 50.0 & 9.4 & $---^{y}$ \\
\hline C. heterophylla (HET) & 26.8 & 23.4 & 29.5 & 15.2 & 80.0 & 27.8 & 42.8 & 56.3 & 50.0 \\
\hline C. cornuta $(\mathrm{COR})$ & 43.2 & 4.2 & 42.2 & 88.9 & 0.0 & 0.0 & 100.0 & 100.0 & 100.0 \\
\hline C. californica (CAL) & 100.0 & 54.9 & 54.6 & 25.0 & 28.6 & 31.7 & 35.8 & 28.6 & --- \\
\hline C. sieboldiana (SIE) & 33.5 & 54.2 & 56.4 & 27.6 & 39.1 & 17.2 & 38.1 & 41.3 & 64.7 \\
\hline C. colurna (COL) & 100.0 & 48.7 & 82.2 & 100.0 & 47.5 & 28.4 & 22.9 & 50.0 & --- \\
\hline C. chinensis (CHI) & 25.8 & 4.6 & --- & --- & --- & 75.0 & --- & 19.5 & --- \\
\hline
\end{tabular}

${ }^{\mathrm{z}}$ Corylus heterophylla var. sutchuensis. Abbreviations for other species are given in the first column.

${ }^{\mathrm{y}}$ Hyphens indicate crosses for which no seeds were obtained.

induced 1242 seeds out of 1316 to germinate in $42 \mathrm{~d}$. Germination was monitored for the remaining 74 seeds for another $95 \mathrm{~d}$. Of those, however, 23 never germinated (six from C. cornuta $\times$ C. cornuta, five from $C$. cornuta $\times$ C. californica, four from $C$. californica $\times$ C. californica, and two each from C. americana $\mathrm{X}$ C. americana, C americana $\times C$. sieboldiana, C. cornuta $\times C$. heterophylla, and C. sieboldiana $\times$ C. cornuta).

In normal embryos, the embryonic axis is located at the top or tip (pointed side) of the kernels where the two cotyledons are joined together. During germination this embryonic axis produces a thick, fleshy root and shoot tip. However, in some abnormal embryos, roots emerged from the side of the kernel between the cotyledons. In many instances, several fine roots rather than a single root emerged from the embryonic axis. Many of the abnormal embryos formed weak roots but no shoot, and they eventually died.

Hybrid seed germination ranged from $28 \%$ to $94 \%$ (Table 5). High germination was between $70 \%$ to $90 \%$. Although $100 \%$ germination occurred occasionally, these were obtained from very small numbers of incompatible crosses (e.g., C. avellana $\mathrm{x}$ $C$. cornuta or $C$. colurna $\times$ C. americana). Cross-compatible combinations usually resulted in higher seed germination than incompatible crosses. Germination of intraspecific $C$. cornuta seeds was lowest $(36 \%)$ among the species, probably due to higher chilling requirements. In C. colurna $\times$ C. chinensis and their reciprocal, seed germination was very high, $74 \%$ and $95 \%$, respectively. In C. americana $\times C$. heterophylla and their reciprocal, germination was also very high, $76 \%$ and $75 \%$, respectively. Some reciprocal differences in germination were observed. For example, seed germination was only $28 \%$ in $C$. avellana $\times$ C. americana while the reciprocal resulted in $82 \%$.

Once germinated seeds reached the seedling stage, most of them survived (Table 6), with two notable exceptions. Only $42 \%$ of the C. californica $\times$ C. colurna and none of the C. heterophylla $\mathrm{x} C$. avellana seedlings survived. These seedlings were very weak, stopped growing after reaching a height of 20 to $50 \mathrm{~cm}$, and then died. During the early growth of seedlings from 1995 crosses, chlorosis was noted on 158 seedlings, nearly all of them (89\%) were seedlings of C. cornuta, C. californica or $C$. sieboldiana. Powdery mildew (Phyllactinia guttata Lev.) symptoms were noted on 115 seedlings, $65 \%$ of them from C. californica $\times$ C. californica and $15 \%$ of them from C. californica $\times$ C. cornuta crosses. Both chlorosis and powdery mildew symptoms disappeared later in the season.

Seedling vigor, recorded as stem diameter, was highly variable among the interspecific crosses (Table 7). In general, the cultivated hazelnut $C$. avellana, and the tree hazel species $C$. colurna and $C$. chinensis yielded very vigorous interspecific hybrid seedlings. The weakest were intraspecific $C$. cornuta $(0.37 \mathrm{~cm})$ and $C$. heterophylla $(0.41 \mathrm{~cm})$ seedlings. The cross of these two species also resulted in weak seedlings $(0.42 \mathrm{~cm})$. Corylus avellana seedlings were the most vigorous of the intraspecifics $(1.06 \mathrm{~cm})$. Hybrid vigor was noted in some combinations such as $C$. americana $\times C$. californica, but not in the reciprocal, as stem diameter was larger in the interspecific hybrids than in either parent species.

\section{Discussion}

Interspecific crosses, hybrid seed germination tests, and seedling growth data confirm the statement of Thompson et al. (1996) that some Corylus species freely intercross, some can be crossed with difficulty, some can be crossed in only one direction, and others cannot be crossed in either direction. The assignment of

Table 5. Percent seed germination in intra- and interspecific crosses of Corylus species (average of 1995 and 1996).

\begin{tabular}{|c|c|c|c|c|c|c|c|c|}
\hline \multirow[b]{2}{*}{ Female parent } & \multicolumn{8}{|c|}{ Male parent } \\
\hline & AVE & AME & HET & COR & CAL & SIE & COL & $\mathrm{CHI}$ \\
\hline C. avellana (AVE) & 59.0 & 27.7 & 68.8 & 100.0 & $--^{2}$ & 50.0 & 55.0 & --- \\
\hline C. americana (AME) & 82.0 & 73.9 & 76.1 & --- & 90.3 & 66.5 & 41.7 & --- \\
\hline C. heterophylla (HET) & 47.9 & 75.0 & 51.0 & --- & --- & --- & --- & --- \\
\hline C. cornuta $(\mathrm{COR})$ & --- & 87.5 & 57.2 & 35.8 & 72.9 & 49.6 & --- & --- \\
\hline C. californica (CAL) & 49.9 & 50.0 & 76.7 & 44.8 & 52.4 & 65.9 & 76.2 & --- \\
\hline C. sieboldiana (SIE) & --- & 100.0 & 62.5 & 71.0 & 85.6 & 83.4 & --- & --- \\
\hline C. colurna $(\mathrm{COL})$ & 83.3 & 100.0 & 50.0 & --- & --- & --- & 84.0 & 73.8 \\
\hline C. chinensis (CHI) & 94.1 & --- & --- & --- & --- & --- & 94.4 & --- \\
\hline
\end{tabular}

${ }^{\mathrm{z}}$ Hyphens indicate crosses for which no seeds were obtained. 
Table 6. Percent survival of seedlings from intra- and interspecific crosses of Corylus species (average of 1995-96).

\begin{tabular}{|c|c|c|c|c|c|c|c|c|}
\hline \multirow[b]{2}{*}{ Female parent } & \multicolumn{8}{|c|}{ Male parent } \\
\hline & $\overline{A V E}$ & AME & HET & COR & CAL & SIE & $\mathrm{COL}$ & $\mathrm{CHI}$ \\
\hline C. avellana (AVE) & 89.2 & 96.9 & 100.0 & $100.0^{z}$ & $--^{y}$ & $100.0^{z}$ & $100.0^{z}$ & --- \\
\hline C. americana (AME) & 98.5 & 89.9 & 98.5 & --- & 100.0 & 84.7 & 91.7 & --- \\
\hline C. heterophylla (HET) & 0.0 & $100.0^{\mathrm{z}}$ & 86.3 & --- & --- & --- & -- & --- \\
\hline C. cornuta (COR) & --- & $100.0^{\mathrm{z}}$ & 79.8 & 77.8 & 71.7 & 71.1 & --- & --- \\
\hline C. californica (CAL) & 87.5 & 90.0 & 93.8 & 89.1 & 84.8 & 100.0 & 91.7 & --- \\
\hline C. sieboldiana (SIE) & --- & 0.0 & $100.0^{\mathrm{z}}$ & 79.7 & 91.1 & 87.6 & --- & --- \\
\hline C. colurna (COL) & $100.0^{\mathrm{z}}$ & $100.0^{\mathrm{z}}$ & $100.0^{\mathrm{z}}$ & --- & --- & --- & 86.6 & 87.2 \\
\hline C. chinensis (CHI) & 86.7 & --- & --- & --- & --- & --- & 94.1 & --- \\
\hline
\end{tabular}

${ }^{\mathrm{z}}$ Survival based on five or fewer seedlings.

yHyphens indicate crosses for which no seeds were obtained.

Corylus species to three groups facilitates discussion of the results. The low cluster set of many crosses in 1995 was probably due to the flowers being quite old at the time of pollination. Use of stored pollen in 1996 and 1997 resulted in higher set.

In general, the success of the crosses involving $C$. avellana was higher when it was used as a pollen parent. Crosses of $C$. avellana $\times$ C. cornuta gave essentially no set. We made more than 1500 pollinations and obtained only one seedling, which did not appear to be a true hybrid. All nuts from the reciprocal cross were blank. Contrary to our results, Gellatly (1950, 1956, 1964) reported obtaining interspecific hybrids named filazels, which he obtained by removing catkins from $C$. cornuta and assuming that the resulting seeds had resulted from pollination by $C$. avellana. Because his crosses were not performed under controlled conditions, true origin of the resulting seedlings is in doubt. However, a successful backcross of Gellatly's filazel no. 45 to C. avellana was reported by Mehlenbacher (1991).

A similar experience was encountered in C. avellana $\mathrm{x} C$. sieboldiana. Over 1500 pollinations resulted in only one viable seedling, which did not appear to be a true hybrid. No nuts were obtained from the reciprocal cross. In the Republic of Korea, $C$. sieboldiana clones have been hybridized with introduced $C$. avellana cultivars (Kim, 1985). A selection named Gaem \#2 (C. sieboldiana No. $9 \times 76-1$ where 76-1 =C. heterophylla $\times$ 'Butler') was reported. Results in Korea indicate that $C$. sieboldiana must be used as the female parent in crosses with $C$. avellana (Cho, personal communication).

Schuster (1924), was the first to report that the cross $C$. avellana $\times$ C. californica was not compatible, but Mehlenbacher (1991) was successful in making the reciprocal cross. Our data confirm that $C$. avellana is unilaterally compatible with $C$. californica. Several interspecific hybrids have been obtained using several $C$. californica selections as female parents in crosses with $C$. avellana (Mehlenbacher, unpublished data). In our study, seeds were obtained when $C$. californica was crossed with all other Corylus species, indicating that $C$. californica could serve as a bridge species in interspecific hybridization.

Gellatly (1966) described 'Chinoka', a presumed hybrid of $C$. chinensis $\mathrm{x}$ C. avellana. Hybridity was assumed because it did not result from a controlled cross, and Thompson et al. (1996) placed this cross in "uncertain crossability group". The identity of Gellatly's $C$. chinensis parent is also in doubt, because the resulting hybrid seedlings more closely resemble $C$. colurna than C. chinensis. Our results show that pollen of C. avellana provides good set on $C$. chinensis pistillate flowers and only $26 \%$ blank nuts. Most of the hybrid seeds germinated and the seedlings survived. In fact, the vigor of these seedlings was the highest among all Corylus hybrids. The reciprocal cross was unsuccessful. The success of our $C$. chinensis $\times C$. avellana crosses is encouraging, and indicates that such crosses might be promising for transferring the nonsuckering trait from a tree hazel species.

We were able to cross $C$. avellana with $C$. americana in both directions, and morphological traits indicated that the resulting seedlings were true hybrids. Jones was the first to report that this cross was successful only if $C$. americana was used as the pistillate parent (Reed, 1936). But according to Slate (1961), both species hybridize with each other. McKay (1966) observed cytogenetic abnormalities and sterility in some second generation hybrids. Seed germination was higher when $C$. americana was the female parent.

Set on our C. heterophylla x C. avellana crosses was lower than expected, and may be due partly to the low flower quality at time of pollination and the later than ideal time of pollination. Corylus heterophylla flowers were pollinated at budbreak in the

Table 7. Seedling vigor of intra- and inter-specific hybrids of Corylus species expressed as stem diameter (in centimeters) (average of 1995-96).

\begin{tabular}{|c|c|c|c|c|c|c|c|c|}
\hline \multirow[b]{2}{*}{ Female parent } & \multicolumn{8}{|c|}{ Male parent } \\
\hline & AVE & AME & HET & COR & CAL & SIE & $\mathrm{COL}$ & $\mathrm{CHI}$ \\
\hline C. avellana (AVE) & 1.06 & 0.98 & 1.04 & 1.20 & $--^{z}$ & 0.67 & 1.09 & --- \\
\hline C. americana (AME) & 0.86 & 0.60 & 0.58 & --- & 0.96 & 0.63 & 0.72 & --- \\
\hline C. heterophylla (HET) & --- & 0.28 & 0.41 & --- & --- & --- & --- & --- \\
\hline C. cornuta $(\mathrm{COR})$ & --- & 0.51 & 0.42 & 0.37 & 0.61 & 0.54 & --- & --- \\
\hline C. californica (CAL) & 0.82 & 0.56 & 0.69 & 0.67 & 0.76 & 0.79 & 0.42 & --- \\
\hline C. sieboldiana (SIE) & --- & --- & 0.49 & 0.39 & 0.64 & 0.44 & --- & --- \\
\hline C. colurna (COL) & 0.96 & 0.85 & 0.54 & --- & --- & --- & 0.60 & 1.00 \\
\hline C. chinensis (CHI) & 1.26 & --- & --- & --- & --- & --- & 1.03 & --- \\
\hline
\end{tabular}

${ }_{\mathrm{z}}$ Hyphens indicate crosses for which no seedlings were available. 
spring as temperatures were increasing and small leaves were emerging. It was only then that styles of the female flowers became visible, and the styles of most of those females stayed in the bud. In summer, many leaves suffered from sunburn. Flowering of the $C$. heterophylla accessions that we used appeared to be somewhat abnormal. They may have been poorly adapted to the climate of Oregon's Willamette Valley. Thompson et al. (1996) reported low to moderate $(21 \%)$ set in C. heterophylla (clone HF13) x C. avellana OSU 55.129 but failure in the reciprocal cross. This same $C$. heterophylla clone has been successfully crossed with other $C$. avellana genotypes, but other $C$. heterophylla selections used as females have failed to set. In fact, many $C$. heterophylla accessions have never set nuts in the field in Corvallis. In the Chinese hazelnut breeding program, C. heterophylla $\mathrm{x}$ C. avellana crosses yield better set than the reciprocal (Liang and Zhang, 1988; Liang et al., 1994). In Korea, C. heterophylla is used as a female parent in crosses with $C$. avellana, and some $C$. heterophylla selections set well but others do not (Cho, personal communication). In this study, we obtained hybrid seedlings from $C$. avellana $\times$ C. heterophylla but not the reciprocal as stated above. Although a few seeds were obtained from the $C$. heterophylla $\times$ C. avellana cross, most of the seeds were not viable and the resulting seedlings did not survive. The related cross $C$. avellana $\times$ C. heterophylla var. sutchuensis also provided good seed set but a high frequency of blanks. We were unable to attempt the reciprocal of this cross. In summary, $C$. heterophylla and $C$. avellana can be hybridized in both directions, but set may be moderate, low, or zero depending on the parental clones. Liang and Zhang (1988) placed C. heterophylla var. sutchuensis in a separate species, C. kweichowensis $\mathrm{Hu}$.

Kasapligil $(1963,1964)$ does not believe that crosses between C. colurna and $C$. avellana are possible in either direction, but Gellatly (1966) reported some hybrids and named them trazels. Gellatly's (1966) selections resulted from open-pollination of $C$. colurna trees, but morphological traits indicate that they are indeed true hybrids. Two of those hybrids, 'Morrisoka' and 'Faroka,' were backcrossed to $C$. avellana and $C$. colurna by Farris (1982). Our data indicate that crossability between these two species is difficult but possible, and morphological traits indicate that the seedlings we obtained from both directions are true hybrids. Corylus colurna $\times$ C. avellana resulted in cluster set every year, but more than $90 \%$ of the nuts were blank. Nonetheless, five viable seedlings were obtained. In contrast, the reciprocal was successful only in 1996 and only one seedling was obtained. Breeders interested in this interspecific cross should make a large number of pollinations and expect only a few hybrid seedlings.

Many interspecific crosses were attempted for the first time in this study. For example, the previously unreported cross $C$. chinensis $\mathrm{x} C$. americana was compatible and only a few nuts $(<5 \%)$ were empty, while set in the reciprocal was very low and resulted in only two nuts. Corylus americana $\times$ C. sieboldiana produced many true hybrids, but the reciprocal failed. Hundreds of pollinations resulted in only one seedling, which did not appear to be a true hybrid.

As a maternal parent, C. americana was hybridized successfully with the Asian species $C$. heterophylla and $C$. heterophylla var. sutchuensis. These American and Asian species are geographically separated yet quite similar in growth habit and husk morphology. Set was good when $C$. americana pistillate flowers were pollinated with $C$. heterophylla pollen, and many true hybrid seedlings were obtained. The reciprocal cross failed.
Farris (1970) reported a successful cross of $C$. americana $\times$ C. heterophylla var. sutchuensis.

Percent cluster set was $<5 \%$ in $C$. americana $\times C$. cornuta and in the reciprocal. Only three very weak seedlings were obtained from the reciprocal. According to Drumke (1964), these two North American species are distinct in morphology. Their ranges overlap slightly but few, if any, interspecific hybrids are formed. Corylus californica $\times$ C. americana resulted in higher percent set than the reciprocal but the resulting seedlings may not be true hybrids. The seedlings resulting from the reciprocal cross made in 1995 and 1996, however, appear to be true hybrids.

Crosses of $C$. americana with $C$. colurna pollen yielded poor set. Four of the nine resulting seedlings appear to be true hybrids, but the two seedlings from the reciprocal cross do not appear to be true hybrids. Reed (1936) reported set from $C$. colurna pollen on female inflorescences of $C$. americana 'Littlepage' and bark appearance of the seedlings was typical of the pollen parent. In our study, very few nuts were obtained from this cross, and most were blanks.

The cross between the two Asian species, $C$. sieboldiana $\mathrm{x} C$. heterophylla, was very difficult. Percent cluster set was very low, and the resulting nuts were mostly blank. However, a few true hybrid seedlings were obtained. In the reciprocal, cluster set was nearly zero and all of the resulting seeds were blank. Set of $C$. sieboldiana $\times$ C. heterophylla var. sutchuensis was also very low and all of the nuts were blanks. In Korea, a cross of $C$. sieboldiana x (C. heterophylla x C. avellana) was reported by Kim (1985). Crosses of the Asian species Corylus heterophylla $\mathrm{x} C$. chinensis and $C$. chinensis $\times$ C . sieboldiana were not compatible in either direction.

Corylus heterophylla was cross-compatible as a pollen parent with the three North American species, C. cornuta, C. californica, and $C$. americana, and the resulting seedlings appear to be true hybrids. Pollen of C. heterophylla var. sutchuensis was also compatible on $C$. californica pistillate flowers but not on $C$. cornuta.

Corylus heterophylla $\times$ C. colurna crosses were not successful while the reciprocal resulted in only one seedling, which may not be a true hybrid. The cross $C$. colurna $\times$ C. heterophylla var. sutchuensis failed similarly. According to Farris (1976), the reciprocal cross also fails, but we were unable to attempt that cross.

The Asian species $C$. sieboldiana and two North American species $C$. cornuta and $C$. californica were crossed easily in all directions. These crosses had not been attempted previously. As a group, their husk and nut morphology are very similar, and distinct from that of other Corylus species.

Corylus californica presents the most difficult taxonomic problem of the genus in North America. It has been described as a separate species by some authorities (Bailey, 1914; Krussmann, 1976; Rehder, 1940) and a botanical variety of $C$. cornuta by others (Drumke, 1964; Everett, 1981; Huxley et al., 1992; Sharp, 1951; Thompson et al., 1996). Although interpretation of crossing behavior in a phylogenetic context is usually not straightforward, it indicates at least some degree of genomic similarity (Bohs, 1991). In this context, our crossing results support Drumke (1964), who, after a detailed study of herbarium specimens of this species complex, concluded that $C$. californica is a true botanical variety of $C$. cornuta. Likewise, in addition to observed morphological similarities, the high reciprocal cross-compatibility between $C$. sieboldiana and the North American species $C$. cornuta and $C$. californica likely indicate a close relationship. 
Most Corylus species are Asiatic (Drumke, 1964). The two North American species may have descended from Asia (i.e., $C$. americana from $C$. heterophylla, and $C$. cornuta from $C$. sieboldiana) or have had common ancestors. However, no extant Asiatic hazelnuts are identical to those of North America, though some are very similar. Drumke (1964) hypothesized that as Corylus migrated from Asia to North America, a gradual change took place creating a cline between Asian and North American materials. When the Pleistocene glaciers covered the northern part of North America, the intermediate forms between the Asian ancestors and the southernmost plants in America would perhaps have been eliminated.

The low vigor of some interspecific hybrid seedlings (hybrid weakness or inviability) were attributed by Hadley and Openshaw (1980) to incompatibility 1) between the genomes of the parental species, 2) between the genome of one species and the cytoplasm of the other, or 3) between the genotype of the $F_{1}$ zygote and the genotypes of the endosperm or the maternal tissue with which the developing $F_{1}$ embryo is associated.

Some seedlings, notably those of the bristle-husked species, were chlorotic until late in the season. The potting soil used was developed for $C$. avellana seedlings. Seedlings of other species may have different nutritional requirements and thus not perform as well in the same medium. Experience has indicated that seedlings of $C$. americana and $C$. heterophylla and hybrids of these two species with $C$. avellana frequently stop growing in this soil mix, and occasional foliar application of $\mathrm{GA}_{3}$ may be needed for constant growth. The low vigor of these two species may reflect different nutritional requirements.

In summary, many interspecific hybrid combinations are possible in the genus Corylus. Based on percent cluster set, seed germination, and hybrid seedling survival along with observed morphological similarities, Corylus species were placed in three groups: 1) the tree hazels $C$. colurna, and $C$. chinensis, 2) the bristle-husked shrub species $C$. cornuta, $C$. californica, and $C$. sieboldiana, and 3) the leafy-husked shrub species $C$. avellana, $C$. americana, C. heterophylla, and C. heterophylla var. sutchuensis. The performance and fertility of the resulting interspecific hybrid progeny remain to be evaluated. Unfortunately, no bearing trees of $C$. ferox were available for use in this study.

\section{Literature Cited}

Ayfer, M., A. Uzun, and F. Bas. 1986. Turkish hazelnut cultivars (in Turkish). Black Sea Hazelnut Exporters Union, Giresun/Ankara, Turkey.

Bailey, L.H. 1914. The standard cyclopedia of horticulture. vol. 2. Macmillan Co., London.

Bohs, L. 1991. Crossing studies in Cyphomandra (Solanaceae) and their systematic and evolutionary significance. Amer. J. Bot. 78:16831693.

Drumke, J.S. 1964. A systematic survey of Corylus in North America. $\mathrm{PhD}$ diss. Univ. Tenn., Knoxville.

Erdogan, V. and S.A. Mehlenbacher. 1997. Preliminary results on interspecific hybridization in Corylus. Acta Hort. 445:65-71.

Everett, T.H. 1981. The New York Botanical Garden illustrated encyclopedia of horticulture. vol. 3. Garland Publishing, New York.

Farris, C.W. 1970. Inheritance of parental characteristics in filbert hybrids. Annu. Rpt. N. Nut Growers Assn. 61:54-58.

Farris, C.W. 1976. An introduction to the stars: A new family of filbert hybrids. Annu. Rpt. N. Nut Growers Assn. 67:80-82.

Farris, C.W. 1982. A progress report on the development of $F_{2}$ hybrids of Corylus colurna x C. avellana. Annu. Rpt. N. Nut Growers Assn. 73:15-16.
Farris, C.W. 1989. Two new introductions: 'Grand Traverse' hazelnut and 'Spartan' seedless grape. Annu. Rpt. N. Nut Growers Assn. 80:102-103.

Gellatly, J.U. 1950. Description of filazel varieties. Annu. Rpt. N. Nut Growers Assn. 41: 116-117.

Gellatly, J.U. 1956. Filazels. Annu. Rpt. N. Nut Growers Assn. 47:112114.

Gellatly, J.U. 1964. Filazels. Annu. Rpt. N. Nut Growers Assn. 55:153155.

Gellatly, J.U. 1966. Tree hazels and their improved hybrids. Annu. Rpt. N. Nut Growers Assn. 57:98-101.

Hadley, H.H. and S.J. Openshaw. 1980. Interspecific and intergeneric hybridization, p. 133-159. In: W. Fehr and H. Hadley (eds.). Hybridization of crop plants. Amer. Soc. Agron.-Crop Sci. Soc. Amer., Madison, Wis.

Huxley, A., M. Griffiths, and L. Margot. 1992. The new Royal Horticultural Society dictionary of gardening 1. Macmillan Press Ltd., London.

Kasapligil, B. 1963. Corylus colurna and its varieties. Calif. Hort. Soc. J. 24:95-104.

Kasapligil, B. 1964. A contribution to the histotaxonomy of Corylus (Betulaceae). Adansonia 4(1):43-90.

Kasapligil, B. 1972. A bibliography on Corylus (Betulaceae) with annotations. Annu. Rpt. N. Nut Growers Assn. 63:107-162.

Kim, J.H. 1985. Horticultural crops research highlights 1984-85. Hort. Expt. Sta., Rural Dev. Admin., Suweon, Korea.

Krussmann, G. 1976. Manual of cultivated broad-leaved trees and shrubs. Timber Press, Portland, Ore.

Lagerstedt, H.B. 1975. Filberts, p. 456-489. In: J. Janick and J.N. Moore (eds.). Advances in fruit breeding. Purdue Univ. Press, West Lafayette, Ind.

Liang, W., X. Ming, and X. Wanying. 1994. Studies on hazelnut breeding in northern China. Acta Hort. 351:59-66.

Liang, W.J. and Y.M. Zhang. 1988. Investigation and study of filbert resources in China. Proc. Intl. Symp. Horticultural Germplasm, Cultivated and Wild. Beijing, China. 5-9 Sept. 1988.

McKay, J.W. 1966. Sterility in filbert (Corylus). Proc. Amer. Soc. Hort. Sci. 88:319-324.

Mehlenbacher, S.A. 1991. Hazelnuts (Corylus). Genetic resources of temperate fruit and nut crops. Acta Hort. 290:791-836.

Mehlenbacher, S.A. 1994. Genetic improvement of the hazelnut. Acta Hort. 351:23-38.

Mehlenbacher, S.A. 1997. Revised dominance hierarchy for S-alleles in Corylus avellana L. Theor. Appl. Genet. 94:360-366.

Reed, C.A. 1936. New filbert hybrids. J. Hered. 27:427-431.

Rehder, A. 1940. Manual of cultivated trees and shrubs hardy in North America, 2nd ed. Macmillan, New York.

Rovira, M. 1997. Genetic variability among hazelnut (C. avellana L.) cultivars. Acta Hort. 445:45-50.

Schuster, C.E. 1924. Filberts: II. Experimental data on filbert pollination. Ore. Agr. Expt. Sta. Bul. 208.

Sharp, A.J. 1951. Relationships between the floras of California and southern United States. Contrib. Dudley Herbarium 4:59-61.

Slate, G.L. 1961. The present status of filbert breeding. Annu. Rpt. N. Nut Growers Assn. 52:24-26.

Smith, D.C. and S.A. Mehlenbacher. 1994. Use of Tyvek housewrap for pollination bags in breeding hazelnut (Corylus avellana L.). HortScience 29:918.

Thompson, M.M. 1979a. Genetics of incompatibility in Corylus avellana L. Theor. Appl. Genet. 54:113-116.

Thompson, M.M. 1979b. Incompatibility alleles in Corylus avellana L. cultivars. Theor. Appl. Genet. 55:29-33.

Thompson, M.M., H.B. Lagerstedt, and S.A. Mehlenbacher. 1996. Hazelnuts, p. 125-184. In: J. Janick and J.N. Moore (eds.). Fruit breeding. vol. 3. Nuts. Wiley, New York.

Weschcke, C. 1970. A little nut history. Annu. Rpt. N. Nut Growers Assn. 61:113-116. 